\title{
Pengaruh Pemberian Pasta Tomat (Solanum Lycopersicum) terhadap Kualitas Spermatozoa Tikus Wistar (Rattus Norvegicus) yang Terpapar Asap Rokok
}

\author{
${ }^{1}$ Prilly P. Gunawan \\ ${ }^{2}$ Grace L. A. Turalaki \\ ${ }^{2}$ Lydia E. N. Tendean
}

${ }^{1}$ Program Studi Pendidikan Dokter Fakultas Kedokteran Universitas Sam Ratulangi Manado

${ }^{2}$ Bagian Biologi Fakultas Kedokteran Universitas Sam Ratulangi

Email: gunawanprilly@yahoo.com

\begin{abstract}
Lycopene is a potent antioxidant that provides protection against spermatozoa cell damage due to cigarette smoking. The high number of conjugated double bonds makes lycopene has a singleton oxygen cooling ability higher than beta-carotene and alphatocopherol. This was an experimental study with the post test only control group design. The dependent variables in this study were spermatozoa quality which included motility, morphology, and concentration while the independent variables were tomato paste (Solanum lycopersicum) and cigarette smoking. Subjects of this study were 7 Wistar rats (Rattus norvegicus) divided into 2 groups: the control group (P0), exposed to two cigarette smoke per day and the treatment group (P1), given tomato paste once a day. Treatment was given for 48 days. Based on data analysis, the results showed significant differences in spermatozoa motility and morphology of the control and treatment groups $(P<0.05)$, but in spermatozoa concentration the $P$ value was $>0.05$. Conclusion: Tomato paste (Solanum lycopersicum) administration to Wistar rats could improve the spermatozoa motility and morphology significantly but not the spermatozoa concentration.
\end{abstract}

Keywords: sperm quality, lycopene, smoking, cigarette

\begin{abstract}
Abstrak: Likopen merupakan antioksidan kuat yang memberikan perlindungan terhadap kerusakan sel spermatozoa yang disebabkan oleh asap rokok. Tingginya jumlah ikatan rangkap terkonjugasi membuat likopen memiliki kemampuan pendinginan oksigen singleton lebih tinggi dibandingkan beta-karoten dan alpha tocopherol. Jenis penelitian ini ialah eksperimental dengan post test only control group design. Variabel tergantung ialah kualitas spermatozoa yang meliputi motilitas, morfologi, dan konsentrasi sedangkan variabel bebasnya ialah pasta tomat (Solanum lycopersicum) dan asap rokok. Subjek penelitian sebanyak 7 ekor tikus Wistar (Rattus norvegicus) yang dibagi menjadi 2 kelompok yaitu kelompok kontrol (P0), diberikan paparan asap rokok dua batang per hari dan kelompok perlakuan (P1), diberikan pasta tomat satu kali sehari. Perlakuan diberikan selama 48 hari. Berdasarkan analisis data yang dilakukan, hasil penelitian menunjukkan adanya perbedaan bermakna pada motilitas dan morfologi spermatozoa kelompok kontrol dan perlakuan $(P<0,05)$, dan tidak ditemukan pengaruh terhadap konsentrasi spermatozoa $(P>0,05)$. Simpulan: Pemberian pasta tomat (Solanum lycopersicum) pada tikus Wistar jantan dapat memperbaiki motilitas dan morfologi spermatozoa secara bermakna, tetapi tidak untuk konsentrasi spermatozoa.
\end{abstract}

Kata kunci: kualitas spermatozoa, likopen, rokok

Stres oksidatif adalah suatu keadaan ketidakseimbangan antara radikal bebas dengan antioksidan, dimana jumlah radikal bebas lebih banyak jika dibandingkan 
dengan antioksidan. Keadaan ini akan meningkatkan jumlah reactive oxygen species (ROS) yang juga akan memengaruhi spermatozoa. Spermatozoa rentan terhadap kerusakan akibat ROS seperti anion superoksida, hidrogen peroksida, dan hidroksil radikal yang dapat menyebabkan kerusakan membran sel sehingga memperburuk fungsi sperma. ${ }^{1}$

Tomat (Solanum lycopersicum) adalah tumbuhan dari famili Solanaceae. Warna merah yang dimiliki tomat disebabkan karena adanya likopen yaitu suatu antioksidan kuat yang memberikan perlindungan terhadap kerusakan spermatozoa yang disebabkan oleh ROS. ${ }^{2-5}$ Berdasarkan penelitian yang dilakukan oleh Agarwal et al. ${ }^{6}$ Konsumsi tomat sebanyak $2 \mathrm{mg}$ per hari selama 3 bulan dapat meningkatkan semen parameter pada laki-laki.

Asap rokok secara negatif berkorelasi dengan spermatozoa. Dalam keadaan fisiologis normal, plasma semen mengandung mekanisme enzim antioksidan yang mampu memadamkan ROS serta melindungi spermatozoa terhadap kemungkinan kerusakan. Asap rokok berhubungan dengan penurunan motilitas, morfologi, dan konsentrasi spermatozoa. ${ }^{2-5}$ Penelitian yang dilakukan oleh Sunil et al. ${ }^{3}$ menunjukkan hasil yang bermakna terhadap penurunan kualitas spermatozoa yang disebabkan oleh asap rokok.

The Global Adult Tobacco Survey (GATS) 2015 menunjukkan jumlah perokok di Indonesia yang berusia 15 tahun ke atas, berjenis kelamin laki-laki mencapai 67\%. ${ }^{6}$ Menurut data Riset Kesehatan Dasar (RISKESDAS) 2013, provinsi tertinggi perokok ialah Kepulauan Riau 27,2\% dan Sulawesi Utara berada pada peringkat ke-6 dengan $24,6 \%{ }^{7}$

Berdasarkan latar belakang ini penulis tertarik untuk melakukan penelitian tentang pengaruh pemberian pasta tomat (Solanum lycopersicum) terhadap kualitas spermatozoa tikus Wistar (Rattus novergicus) yang terpapar asap rokok.

\section{METODE PENELITIAN}

Jenis penelitian ini ialah eksperimental dengan post test only control group design. Penelitian dilakukan di Laboratorium Bagian Biologi Fakultas Kedokteran Universitas Sam Ratulangi Manado dengan rentang waktu penelitian selama 48 hari dari bulan September - November 2017.

Variabel penelitian ini yaitu pasta tomat (Solanum lycopersicum) dan asap rokok sebagai variabel bebas dan kualitas spermatozoa yang meliputi konsentrasi, motilitas, dan morfologi sebagai variabel tergantung.

Hewan coba yang digunakan ialah 7 tikus Wistar (Rattus norvegicus) jantan, usia 12- 15 minggu, dan berat badan 100200 gr. Bahan yang digunakan ialah pelet komersial, air ledeng, pasta tomat 2,97 ml, rokok kretek dengan kandungan tar 23,32 $\mathrm{mg}$ dan nikotin 2,9 $\mathrm{mg}$ per batang rokok, larutan $\mathrm{NaCl} 0,9 \%$, safranin, methanol, kristal violet, akuades. Alat-alat yang digunakan adalah kandang pemeliharaan, bilik hitung haemasitometer Improved Neubauer, dissecting kit, objek gelas, gelas penutup, pipet tetes, cawan petri, kapas, counter, mikroskop listrik, kamera, dan timbangan digital.

Hewan coba diaklimatisasi selama satu minggu dan ditempatkan dalam kandang yang terbuat dari bahan plastik yang ditutup dengan kawat kasa. Hewan coba dibagi menjadi 2 kelompok, yaitu: kelompok kontrol (P0), diberikan paparan asap rokok dua batang per hari; dan kelompok perlakuan (P1), diberikan pasta tomat dengan dosis 2,97 $\mathrm{ml}$ per hari dan paparan asap rokok dua batang per hari. Perlakuan dilakukan selama 48 hari. Pada hari ke-49 semua hewan coba diterminasi dengan cara pembedahan menggunakan dissecting kit untuk mengambil organ reproduksi berupa testis dan kauda epididimis. Testis beserta kauda epididimis yang diambil kemudian dipisahkan dengan cara memotong bagian proksimal korpus epididimis dan bagian distal vas deferens. Potongan kauda epididimis dimasukkan ke dalam cawan petri, lalu diteteskan 3 tetes larutan $\mathrm{NaCl} 0,9 \%$.

Suspensi spermatozoa diteteskan pada kaca objek dengan volume tertentu (tidak 
lebih dari 10 mikroliter) kemudian ditutup dengan kaca penutup. Biarkan 1 menit agar stabil. Amati dengan mikroskop pembesaran 400 kali kemudian nilai motilitas spermatozoa. Untuk kategori motilitas spermatozoa terdiri atas: motilitas A, gerakan spermatozoa maju lurus dan cepat (progresif); motilitas B, spermatozoa bergerak ditempat (non progresif); motilitas $\mathrm{C}$, spermatozoa diam atau tidak bergerak.

Setelah itu, diperiksa 4-6 lapangan pandang untuk mendapatkan 100 spermatozoa secara berurutan, kemudian diklasifikasikan sehingga menghasilkan persentase setiap kategori motilitas.

Untuk pengamatan morfologi, suspensi spermatozoa diteteskan di atas kaca objek, dibuat preparat hapus dan dikeringkan di udara. Selanjutnya sediaan hapus difiksasi dengan methanol selama 5 menit, kemudian dikeringkan.Setelah kering, sediaan hapus dilakukan pewarnaan dengan safranin selama 5 menit, kemudian preparat dibilas dengan air mengalir. Sediaan hapus diwarnai dengan kristal violet selama 1 menit. Setelah itu, sediaan dibilas dan dikeringkan. Setelah kering, amati di bawah mikroskop dengan perbesaran 100 kali kemudian 400 kali. Diambil tiga lapang pandang untuk menentukan presentase morfologi spermatozoa normal dan abnormal pada satu preparat. Dicatat bentuk/kelainan tiap spermatozoa pada setiap lapang pandang dan terakhir dihitung persentase morfologi spermatozoa yang normal dan abnormal.

Untuk pengamatan konsentrasi spermatozoa, suspensi spermatozoa yang telah diperoleh terlebih dahulu dihomogenkan dengan cara diaduk dengan gelas pengaduk. Selanjutnya suspensi spermatozoa dihisap dengan pipet leukosit sebanyak 0,5 ml sampel, setelah itu dihisap cairan pengencer dalam pipet sampai tanda 11 . Suspensi spermatozoa diteteskan pada bilik hitung hemasitometer Improved Neubauer lalu diamati dibawah mikroskop dengan pembesaran 400 kali.

Cara perhitungan spermatozoa dilakukan dengan membagi 1 lapang pandang menjadi 4 kuadran, kemudian hitung jumlah spermatozoa yang terdapat dalam masing-masing kuadran. Setelah itu dijumlahkan total spermatozoa yang terdapat dalam setiap kuadran dan dikalikan 50.000 .

Analisis data yang dilakukan ialah uji normalitas, uji homogenitas, dan independent T-test.

\section{HASIL PENELITIAN \\ Motilitas spermatozoa}

Setelah diberikan pasta tomat dan paparan asap rokok selama 48 hari pada tikus wistar (Rattus norvegicus) didapatkan hasil rerata motilitas spermatozoa yang dibagi menjadi motilitas kategori A, B. Dan C (Tabel 1). Terdapat perbedaan antara rerata motilitas spermatozoa kategori A, kategori B dan kategori C pada kelompok kontrol (P0) dan kelompok perlakuan (P1). Hasil rerata motilitas spermatozoa kelompok kontrol (P0) kategori A sebesar 26,5\%, kategori B sebesar 40,6\% dan kategori C sebesar 32,9 \% sedangkan untuk kelompok perlakuan (P1) memiliki hasil rerata motilitas spermatozoa kategori A sebesar $48 \%$, kategori B sebesar 38\% dan kategori C sebesar $22 \%$.

Tabel 1. Rerata motilitas spermatozoa tikus Wistar (Rattus norvegicus) setelah diberikan perlakuan

\begin{tabular}{cccc}
\hline $\begin{array}{c}\text { Kelompok } \\
\text { sampel }\end{array}$ & $\mathrm{A}(\%)$ & $\mathrm{B}(\%)$ & $\mathrm{C}(\%)$ \\
\hline Kontrilitas & 26,5 & 40,6 & 32,9 \\
Perlakuan & 48 & 38 & 22 \\
\hline
\end{tabular}

\section{Morfologi spermatozoa}

Setelah diberikan pasta tomat dan paparan asap rokok selama 48 hari pada tikus wistar (Rattus norvegicus) didapatkan hasil rerata morfologi spermatozoa yang dibagi menjadi morfologi normal dan abnormal (Tabel 2). Terdapat perbedaan antara rerata morfologi spermatozoa normal dan abnormal pada kelompok kontrol dan kelompok perlakuan. Hasil rerata morfologi spermatozoa normal kelompok kontrol sebesar 52,5\% dan abnormal sebesar 47,5\% sedangkan untuk kelompok perlakuan 
memiliki rerata morfologi spermatozoa normal sebesar $56,4 \%$ dan abnormal sebesar $43,6 \%$.

Tabel 2. Rerata morfologi spermatozoa tikus Wistar (Rattus norvegicus) setelah diberikan perlakuan

\begin{tabular}{ccc}
\hline $\begin{array}{c}\text { Kelompok } \\
\text { sampel }\end{array}$ & $\begin{array}{c}\text { Morfologi } \\
\text { normal } \\
(\boldsymbol{\%})\end{array}$ & $\begin{array}{c}\text { Morfologi } \\
\text { abnormal } \\
(\boldsymbol{\%})\end{array}$ \\
\hline Kontrol & 52,5 & 47,5 \\
Perlakuan & 56,4 & 43,6 \\
\hline
\end{tabular}

\section{Konsentrasi spermatozoa}

Setelah diberikan pasta tomat dan paparan asap rokok selama 48 hari pada tikus Wistar (Rattus norvegicus) didapatkan hasil rerata konsentrasi spermatozoa Tabel 3). Terdapat perbedaan rerata konsentrasi spermatozoa antara kelompok kontrol yang diberikan paparan asap rokok 2 batang/hari dibandingkan kelompok perlakuan yang diberikan pasta tomat per hari dan paparan asap rokok 2 batang/hari. Rerata konsentrasi spermatozoa kelompok kontrol lebih rendah sebanyak 37,35 x $10^{6}$ sperma/ml suspensi dibandingkan dengan kelompok perlakuan sebanyak 42,31 x $10^{6}$ sperma/ml suspensi.

Tabel 3.Rerata konsentrasi spermatozoa tikus Wistar (Rattus norvegicus) setelah diberikan perlakuan

\begin{tabular}{cc}
\hline $\begin{array}{c}\text { Kelompok } \\
\text { sampel }\end{array}$ & $\begin{array}{c}\text { Konsentrasi } \\
\text { spermatozoa } \\
(\mathbf{x ~ 1 0 \%} / \mathbf{~ m L})\end{array}$ \\
\hline Kontrol & 37,35 \\
Perlakuan & 42,31 \\
\hline
\end{tabular}

\section{Uji komparabilitas antar kelompok penelitian}

Uji komparabilitas digunakan untuk membandingkan rerata kualitas spermatozoa yaitu motilitas spermatozoa, morfologi spermatozoa, dan konsentrasi spermatozoa antar kelompok penelitian yaitu kelompok kontrol yaitu paparan asap rokok dua batang per hari dengan kelompok perlakuan yaitu pemberian pasta tomat per hari dengan paparan asap rokok dua batang per hari. Data yang diperoleh kemudian diolah dan dianalisis. Berdasarkan hasil uji normalitas dan homogenitas, didapatkan data terdistribusi normal dan homogen, maka analisis komparatif yang dilakukan ialah uji-T Independen (Tabel 4).

Tabel 4. Perbandingan kualitas spermatozoa kelompok kontrol $\left(\mathrm{P}_{0}\right)$ dan perlakuan $(\mathrm{P})$

\begin{tabular}{lccc}
\hline $\begin{array}{c}\text { Kualitas } \\
\text { spermatozoa }\end{array}$ & P0 & P1 & $\boldsymbol{P}$ \\
\hline Motilitas A & 26,5 & 48 & 0,002 \\
Motilitas B & 40,6 & 30 & 0,001 \\
Motilitas C & 32,9 & 22 & 0,004 \\
Morfologi & 52,5 & 56,4 & 0,011 \\
Normal & & & \\
Morfologi & 47,5 & 43,6 & 0,020 \\
Abnormal & & & \\
Konsentrasi & 37,35 & 42,31 & 0,220 \\
\hline
\end{tabular}

Hasil uji-T independen kelompok kontrol dan perlakuan mendapatkan nilai $P<0,05$ pada perbandingan motilitas A $(P=0,002), \quad$ motilitas B $\quad(P=0,001)$, motilitas $\mathrm{C}(P=0,004)$, morfologi normal $(P=0,011)$, dan morfologi abnormal $(P=0,020)$ sedangkan pada konsentrasi didapatkan nilai $P>0,05$ yang berarti tidak ada pengaruh yang bermakna pada konsentasi spermatozoa.

\section{BAHASAN \\ Motilitas spermatozoa}

Tabel 1 memperlihatkan rerata perbedaan motilitas spermatozoa dari kelompok kontrol dan kelompok perlakuan. Untuk rerata motilitas A, kelompok kontrol sebesar 26,5\% lebih rendah dibandingkan kelompok perlakuan sebesar $48 \%$. Untuk rerata motilitas $\mathrm{B}$, kelompok kontrol sebesar 40,6\% lebih rendah dibandingkan kelompok perlakuan $38 \%$. Untuk rerata motilitas C, kelompok kontrol sebesar $32,9 \%$ lebih tinggi dibandingkan kelompok perlakuan sebesar $22 \%$.

Berdasarkan uji komparabilitas menggunakan uji t-independent (Tabel 4), untuk motilitas $\mathrm{A}, \mathrm{B}$ dan $\mathrm{C}$ didapatkan nilai sig berturut-turut ialah $(P=0,002)$, $(P=0,001)$, dan $(P=0,004)$; semuanya $P<$ 
0,05 yang menunjukkan terdapat pengaruh perlakuan terhadap motilitas spermatozoa tikus Wistar (Rattus norvegicus). Hal ini sesuai dengan penelitian sebelumnya yang dilakukan Gupta $^{6}$ yang menunjukkan pengaruh pemberian tomat (Solanum lycopersicum) terhadap kualitas spermatozoa.

\section{Morfologi spermatozoa}

Tabel 2 memperlihatkan rerata perbedaan morfologi spermatozoa dari kelompok kontrol dan kelompok perlakuan. Untuk rerata morfologi normal, kelompok kontrol sebesar 52,5 \% lebih rendah dari kelompok perlakuan sebesar $56,4 \%$. Untuk rerata morfologi abnormal, kelompok kontrol sebesar 47,5\% lebih tinggi dari kelompok perlakuan sebesar $43,6 \%$.

Berdasarkan uji komparabilitas menggunakan uji t-independent (Tabel 4), untuk morfologi normal dan abnormal didapatkan nilai $P$ berturut-turut ialah $P=$ 0,011 dan $P=0,020$ dimana keduanya $(P<0,05)$ yang menunjukkan terdapat pengaruh perlakuan terhadap morfologi spermatozoa tikus wistar (Rattus norvegicus). Hal ini sesuai dengan penelitian sebelumnya yang dilakukan Gupta $^{6}$ yang menyatakan bahwa pemberian tomat dapat meningkatkan semen parameter. Menurut Tamilselvan ${ }^{8}$ likopen dapat menurunkan peroksidasi lipid dan kerusakan deoxyribose-nucleic acid (DNA) dalam semen parameter pada lakilaki.

\section{Konsentrasi spermatozoa}

Tabel 3 menmperlihatkan rerata perbedaan konsentrasi spermatozoa dari kelompok kontrol dan kelompok perlakuan. Hasil rerata konsentrasi kelompok kontrol sebesar $37,35 \times 10^{6}$ spermatozoa/ml lebih rendah dibandingkan kelompok

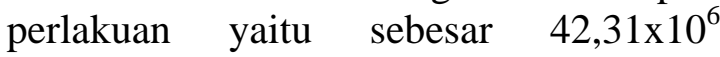
spermatozoa/mL

Berdasarkan uji komparabilitas menggunakan uji t-independent (Tabel 4), didapatkan nilai $P=0,220(P>0,05)$ yang menunjukkan tidak terdapat pengaruh perlakuan terhadap konsentrasi spermatozoa tikus Wistar (Rattus norvegicus). Hal ini tidak selaras dengan penelitian yang dilakukan oleh Durairajanayam ${ }^{9}$ yang menyatakan bahwa konsumsi tomat akan meningkatkan jumlah spermatozoa. Hal ini mungkin disebabkan karena produk olahan tomat yang digunakan berbeda, waktu penelitian yang singkat, dan efek antioksidan terhadap masingmasing tikus Wistar berbeda.

Rokok menjadi salah satu faktor yang dapat menyebabkan kondisi stres oksidatif meningkat. Pada kondisi stres oksidatif terjadi produksi radikal bebas yang berlebihan. Meningkatnya produksi radikal bebas di dalam tubuh dapat menurunkan enzim-enzim antioksidan intrasel dan menyebabkan kerusakan sel spermatozoa. Salah satu produk dari stres oksidatif ialah ROS. Generasi ROS akan menyebabkan peroksidasi lipid sehingga terjadi kerusakan sel, termasuk kehilangan adenosine trifosfat (ATP) intraseluler dalam pemberian energi untuk pergerakan spermatozoa, cacat morfologis, fragmentasi DNA, menurunnya reaksi akrosom dan kemampuan fusiogenik. $^{10}$

Tomat mengandung banyak senyawa antioksidan, diantaranya karetinoid, vitamin $\mathrm{E}$ yang melindungi polyunsaturated fatty acid (PUFA) atau asam lemak tak jenuh dan komponen membran sel dari oksidasi sehingga dapat meningkatkan motilitas sperma. Vitamin $\mathrm{C}$ dan likopen memiliki kemampuan pendingingan oksigen singleton yang lebih baik dari betakaroten dan alphatocopherol sehingga mampu menangkal radikal bebas dan memperbaiki fragmentasi DNA serta peroksidasi lipid yang terjadi. ${ }^{10-11}$

\section{SIMPULAN}

Berdasarkan hasil penelitian mengenai pengaruh pemberian pasta tomat (Solanum lycopersicum) terhadap kualitas spermatozoa tikus Wistar (Rattus norvegicus) yang terapar asap rokok dapat disimpulkan bahwa pemberian pasta tomat berpengaruh positif terhadap kualitas spermatozoa tikus Wistar (Rattus norvegicus) yang terpapar 
asap rokok dalam hal ini motilitas dan morfologi spermatozoa.

\section{SARAN}

Disarankan untuk melakukan penelitian lebih lanjut mengenai pengaruh pemberian pasta tomat terhadap kualitas spermatozoa tikus Wistar yang terpapar asap rokok dengan jumlah sampel yang lebih banyak dan waktu penelitian yang lebih panjang.

\section{DAFTAR PUSTAKA}

1. Sharma R, Agarwal A. Spermatogenesis: an overview. In: Zini A, Agarwal A, editors. Sperm Chromatin: Biological and Clinical Applications in Male. New York: Springer, 2011; p. 22-5.

2. K Balaswamy, P Rao, P Yadav, N Rao, Sulochanamma, A Satyanarayana. Antioxidant activity of tomato (Lycopersicon esculentum L.) of low soluble solids and development of a shelf stable spread. Food Science, Nutrition and Dietetics. 2015;4:202.

3. Sunil, K. Shiva M, V.V. Mishra, A.K. Gautam. Environmental \& Lifestyle factors in deterioration of male reproductive health. Hum Reprod. 2013;140 (Suppl):29-35.

4. Hassan A, Ghanbari M. Effect of cigarette smoke on spermatogenesis in rats. Urology. 2007;4:159-63.
5. Elizabeth A, Kalaiselvi K. Impact of cigarette smoking and alcohol intake on male infertility. Pharmacol. 2013;4(4):(B)5138.

6. Agarwal A, Gupta S, Sharma RK. Role of oxidative stress in male reproducetion. Reprod

Biol Endocrinol. 2005;3(28):383-90.

7. Info Datin. Perilaku Merokok Masyarakat Indonesia berdasarkan RISKESDAS 2007 \& 2013: p. 1-11.

8. Tamilselvan $P$, Bharathiraja $K$, Vijaprakash S, Balasubramanian $M$. Protective role of lycopene on bisphenol a induced changes in sperm characteristics, testicular damage and oxidative stress in rats. Pharmacol. 2013:131-43.

9. Durairajnayagam D, Agarwal A, Ong C, Prashast P. Lycopene and male infertility. Andrology. 2003;16:420-5.

10. Chi H, Kim J, Ryu C, J,S Lee, Park Y, Chung $\mathbf{Y}$ et al. Protective effect of antioxidant supplementation in spermpreparation medium against oxidative stress in human spermatozoa. Hum Reprod. 2008;23(5):1023.

11. Ng Cho Ping, Hashim N, Adli D. Effects of Nigella sativa (Habbatus sauda) oil and nicotine chronic treatments on sperm parameters and testis histological features of rats. Biological. 2014;2014. Article ID 218293. 